To Maega | Jurnal Pengabdian Masyarakat

Februari 2022, Vol.5, No.1, hal, 91-98

$\operatorname{ISSN}(P): 2622-6332 ; \operatorname{ISSN}(E): 2622-6340$

http://www.ojs.unanda.ac.id/index.php/tomaega

\title{
Pelatihan Pembuatan Kemasan Produk-Produk Rumahan Bagi Masyarakat Di Desa Toniku
}

\author{
Mukhlis M+1*, Lita Asyriati Latif ${ }^{1}$, Bambang Tjiroso' ${ }^{1}$, Sandi Rais ${ }^{1}$ \\ ${ }_{1}^{1}$ Program Studi Teknik Mesin Universitas Khairun \\ *Correspondent Email: mukhlis@unkhair.ac.id
}

Article History:

Received: 17-12-2021; Received in Revised: 28-12-2021; Accepted: 11-01-2022

DOI: http://dx.doi.org/10.35914/tomaega.v5i1.964

\begin{abstract}
Abstrak
Tujuan pengabdian ini sebagai bentuk pemberdayaan Masyarakat desa dan kepedulian terhadap nelayan dalam meningkatkan ekonomi mereka, dimana metode yang dilakukan dengan pelatihan pengolahan ikan, pembuatan kemasan, desain, dan proses produksi ikan dalam kemasan bagi masyarkat di desa toniku. Adapun hasil pengabdian telah terlaksana proses pelatihan pada industri rumahan "SARINA", pemberian bantuan kemasan dengan merek "Ikan Teri Khas Tonuki, Sarina Toniku" dan proses pengemasan telah di laksanakan sehingga produk ikan teri kemasan siap untuk di pasarkan
\end{abstract}

Kata Kunci: Pemberdayaan, Pengolahan, ikan, Kemasan, Produksi

\begin{abstract}
The purpose of this service is as a form of empowering rural communities and caring for fishermen in improving their economy, where the method is carried out by training in fish processing, packaging making, design, and the production process of packaged fish for the community in Toniku village. As for the results of the service, the training process has been carried out in the "SARINA" home industry, the provision of packaging assistance with the brand "Tony Anchovy, Sarina Toniku" and the packaging process has been carried out so that packaged anchovy products are ready to be marketed.
\end{abstract}

Key Word: Empowerment, Processing, Fish, Packaging, Production

\section{Pendahuluan}

Kepekaan kita terhadap masyarakat sekitar kita dalam menyelesaikan hal-hal yang dapat membantu keberlangsungan hidup sosial kemasyarakatan sehingga kita di tuntut untuk saling peduli, baik itu bantuan secara materil maupun nonmateril (Mukhlis dkk, 2021). Desa tonikum merupakan salah satu desa yang keseharian mereka bergelut dengan hasil laut berupa ikan laut seperti ikan teri yang di keringkan, namun belum di lakukan pengemasan

Kemasan atau packaging menjadi salah satu andalan pada penjualan suatu produk. Awalnya packaging hanya di fungsikan sebagai wadah atau bungkus yang berguna untuk melindungi, menutupi atau untuk memudahkan suatu produk dibawa, tetapi seiring perkembangan zaman, packaging dituntut untuk mampu menumbuhkan ketertarikan konsumen untuk membeli suatu produk. 
Sebuah kemasan yang baik hendaknya dapat menjadi media komunikasi/promosi yang mendongkrak penjualan suatu produk, karena kemasan (packaging) pada saat ini mengalami pergeseran fungsi yang awalnya hanya melindungi sebuah produk, kini berfungsi sebagai identifikasi sebuah merk dagang Perkembangan (packaging) akhirnya menjadikan bagian ujung tombak dari promosi suatu produk yang akhirnya berfungsi dalam meningkatkan nilai jual produk (Didiharyono dkk, 2018).

Produk-produk masyarakat yang di hasilkan dari industri rumahan yang begitu beragam di Desa Toniku memerlukan perhatian dalam hal pengemasannya. pengetahuan tentang variasi bentuk kemasan yang menarik dan sesuai dengan fungsinya masih belum dipahami oleh pengusaha/pelaku usaha. Masih banyak pelaku usaha yang belum mengetahui tentang kemasan yang baik dan aman, informasi apa saja yang harus dicantumkan dalam sebuah kemasan, serta teknik pengemasan dan desain kemasan yang menarik, serta tidak hanya memberikan keunikan produk dan sebagai pembeda dari produk lain yang memudahkan konsumen memilih suatu produk dibandingkan dengan produk yang lain. Tetapi kemasan juga sebagai alat yang dapat mendorong menigkatkan penjualan, dimana dalam strategi ini pelaku usaha diharapkan agar bisa mempertahankan keadaaan usaha yang sudah mulai berkembang (Raznilawati, 2017).

Desa Toniku berada di Wilayah Kecamatan Jailolo Selatan, Kabupaten Halmahera Barat, Provinsi Maluku Utara, Indonesia. Jumlah penduduk desa ini tahun 2019 berjumlah 1.367 jiwa, dengan luas wilayah $0,51 \mathrm{~km}^{2}$. Mayoritas pekerjaan warga di Desa Toniku adalah sebagai petani, pedagang, nelayan dan ada juga pelaku usaha seperti industri di sektor perikanan.

Industri rumahan yang berada di Desa Toniku kebanyakan dari sektor perikanan. Desa Toniku terkenal dengan penghasil ikan ngafi (ikan teri). Masyarakat Desa Toniku kebanyakan menggantungkan kehidupannya pada usaha perikanan sebagai sumber pendapatan utama. Salah satu industri rumahan yang berada di Desa Toniku adalah usaha ikan ngafi (ikan teri) "SARINA". Industri rumahan ini memiliki 4 buah Bagan Ikan. Sistem penjualan/pemasaran hasil ikan ngafi (ikan teri) masih tradisional yaitu di jual ke pengepul dan dipasarkan ke pasarpasar yang berada di sekitarnya..

Permasalahan utama yang terjadi pada mitra adalah masih kurangnya pemahaman dan pelatihan tentang cara membuat kemasan (packaging) untuk meningkatkan nilai penjualan/pemasaran. Permasalahan tersebut akan di uraikan dalam bagan alir berikut ini. 


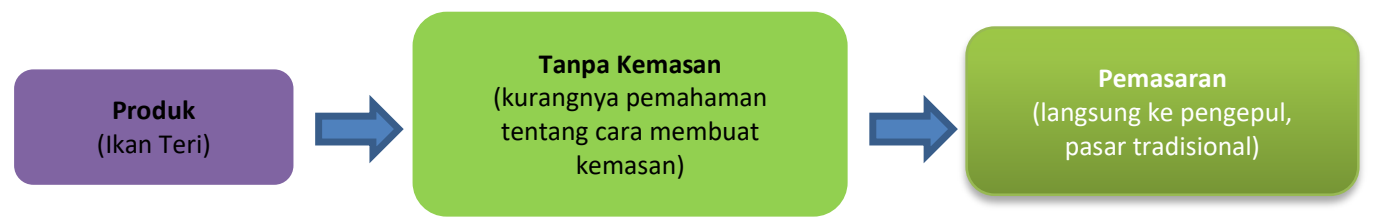

Gambar 1. Bagan Alir Permasalahan Mitra

\section{Metode}

Metode mengatasi permasalahan yang dihadapi mitra industri rumah tangga ikan ngafi (ikan teri) adalah melakukan pelatihan pembuatan kemasan (packaging) untuk meningkatkan nilai jual dari produk.

Program pelatihan produk-produk masyarakat nelayan di desa Toniku ditujukan untuk memberikan pemahaman tentang bagaimana memasrkan dan mengemas hasil produksi iakn teri melalui pelatihan pembuatan kemasan (packaging) untuk meningkatkan nilai jual dari produk.

\section{Hasil dan Pembahasan}

\section{a. Lokasi Program Pelatihan Pembedayaan Masyarakat}

Desa Toniku adalah desa yang berada di pesisir pantai Pulau Halmahera Barat, tepatnya di Kecamatan Jailolo Selatan. Jumlah penduduk desa ini tahun 2019 berjumlah 1.367 jiwa, dengan luas wilayah $0,51 \mathrm{~km}^{2}$. Mayoritas masyarakat di Desa ini adalah Nelayan. Nelayan di Desa Toniku saat ini memiliki 6 buah Bagan Ikan, dimana hasil produksi bagan ikan yang dimiliki kebanyakan adalah Ikan Teri dan Ikan Asin. 6 Buah bagan tersebut juga memiliki rumah-rumah produksi dan pengolahan ikan yang tersebar di Desa Toniku. Titik lokasi bagan ikan di Desa Toniku dapat dilihat pada peta di bawah ini :

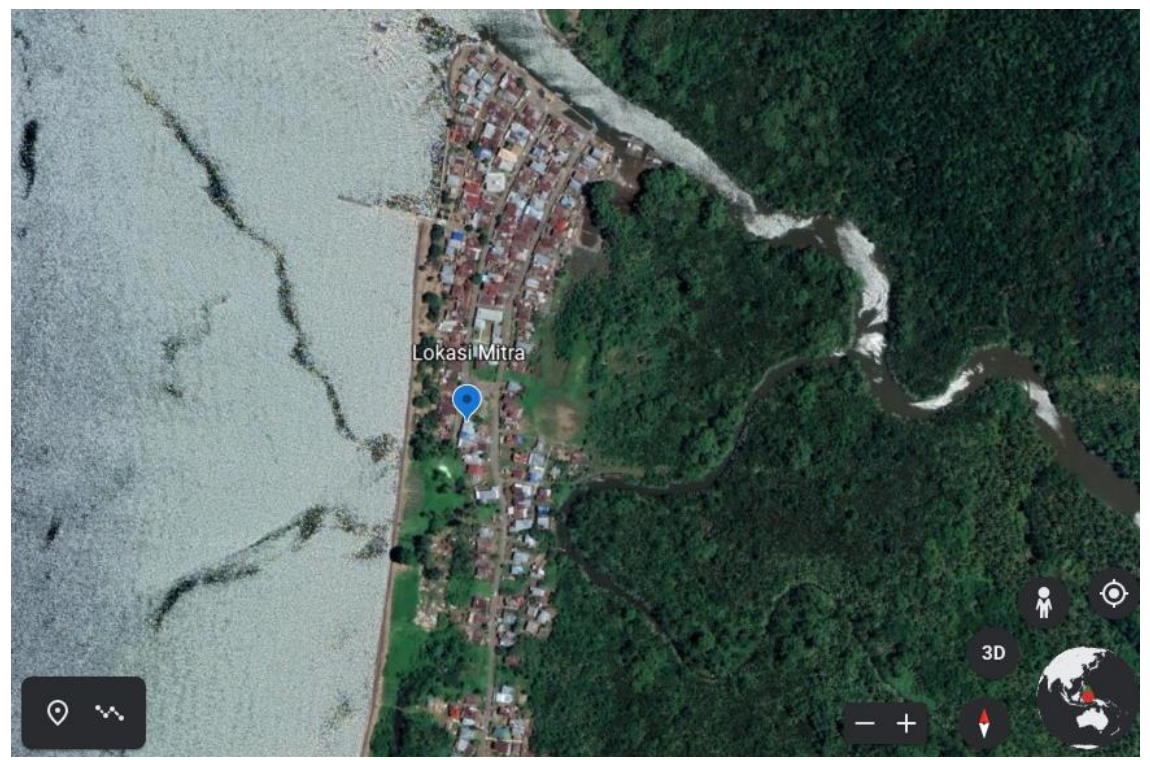

Gambar 1. Peta Lokasi Desa Toniku 


\section{b. Metode Penyaringan dan Proses Produksi Ikan Teri}

Di Desa Toniku, Para Nelayan sebelum memasarkan produk ikan teri terlebih dahuku dilakukan beberapa tahapan produksi antara lain :

1. Penyaringan Ikan

Untuk proses pengeringan ikan yang masih mengunakan metode tradisional perlu dilakukan penelitian lanjutan yaitu dengan pembuatan alat pengering ikan sederhana. Di Program Studi Teknik Mesin beberapa alat pengering telah di kembangkan antara lain alat pengering cengkeh dan alat pengasalapan ikan. Alat pengering ini akan dilakukan modifikasi sehingga dapat di aplikasikan sebagai alat pengering ikan bagi masyarakat nelayan di Desa Toniku

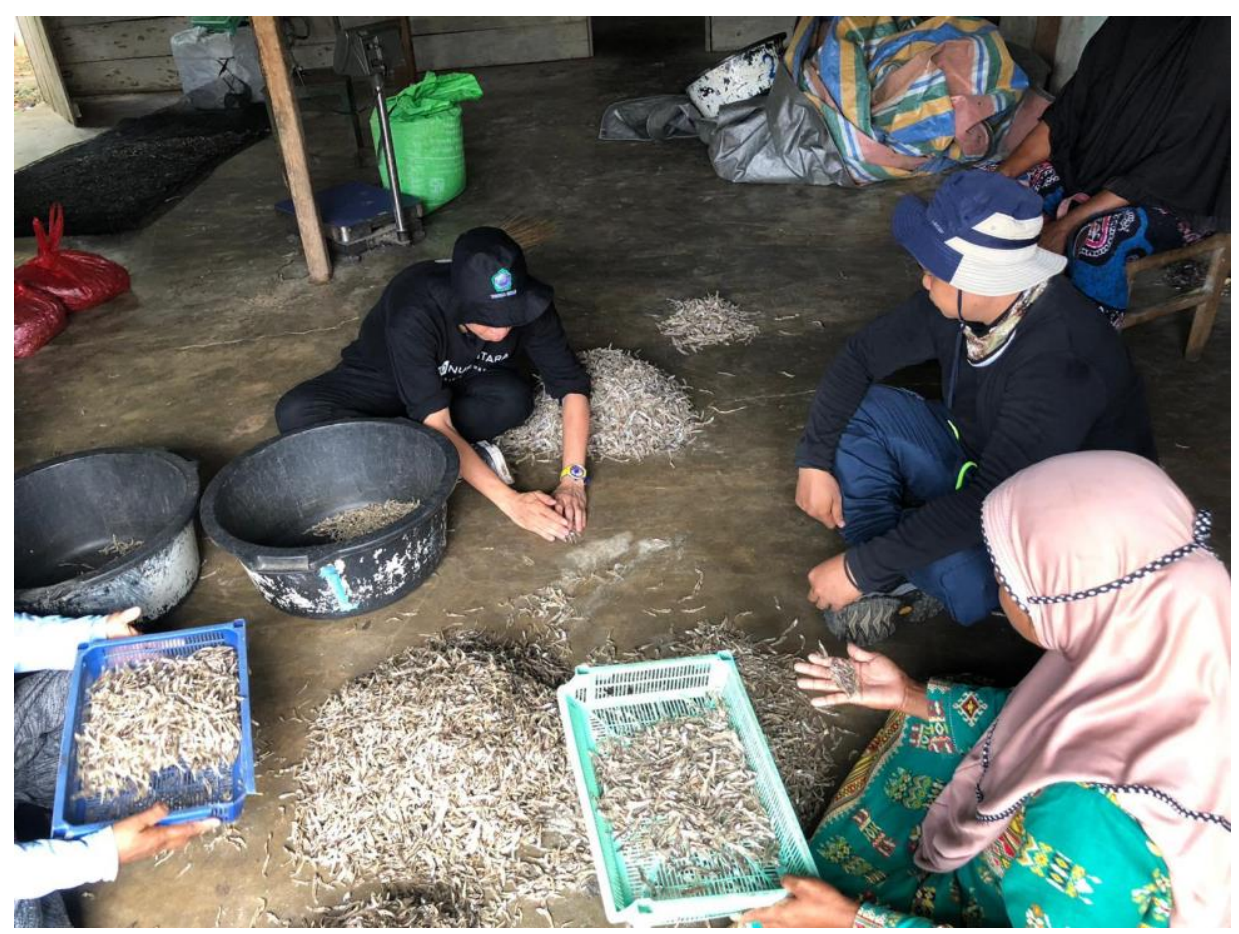

Gambar 2. Penyaringan Ikan

2. Pengepulan Ikan Teri di Gudang

Setelah melakukan penyaringan ikan dalam hal ukuran besar kecilnya ikan, tahapan selanjutnya adalah Penyimpanan atau pengepulan Ikan di Gudang penyimpanan. Pada tahapan ini ikan hanya di biarkan tanpa dilakukan pengemasan. 


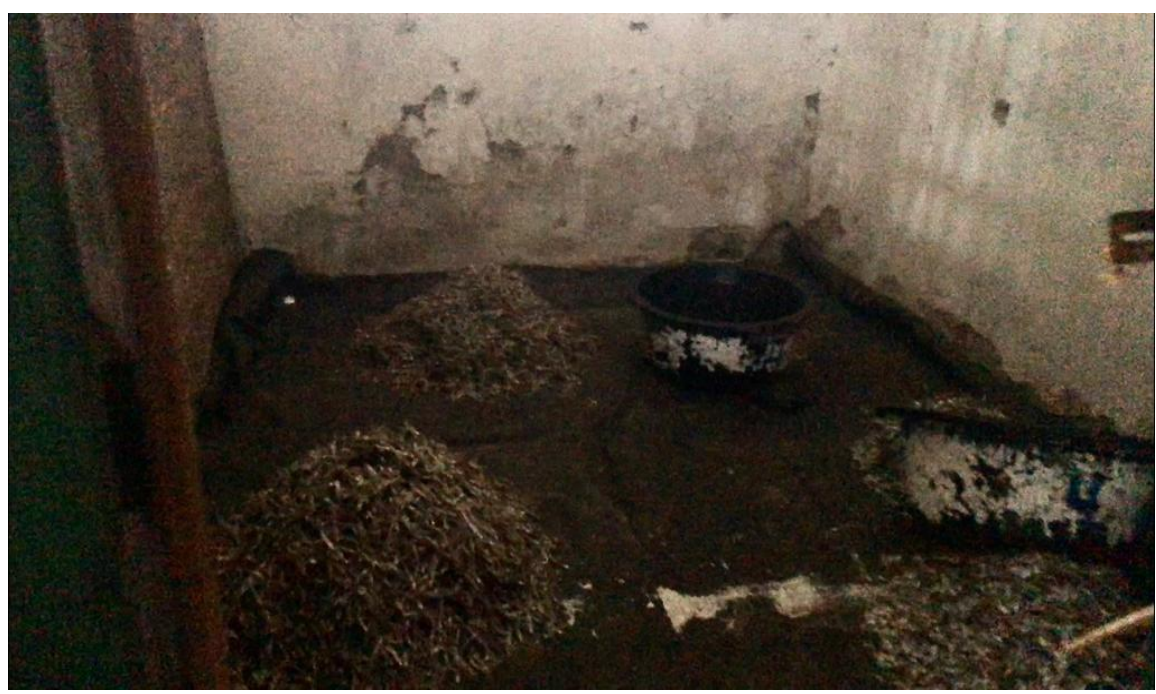

Gambar 3. Pengepulan Ikan

3. Pengemasan Tradisional

Proses pemesanan ikan dilakukan apabila ada pembeli yang datang untuk memberi ikan secara langsung. Pengemasan hanya dilakukan dengan menggunakan kantong plastik (kresek)

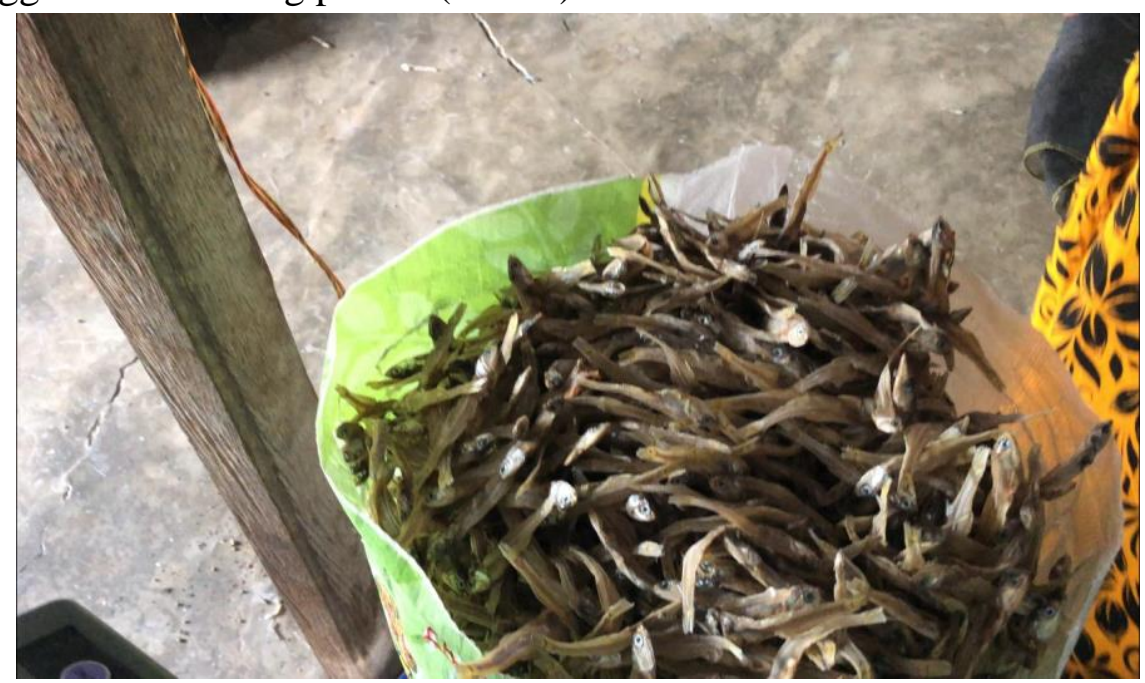

Gambar 4. Metode Pengolahan Ikan di Desa Toniku

Pada Gambar 3 dan 4 terlihat bahwa, secara higienis proses penyimpanan dan pengemasan Ikan Teru yang dilakukan oleh para Nelayan sangat tidak layak. Untuk lebih meningkatkan kualitas dari produk kemasan Ikan Teri maka ruangan penyimpanan (pengepulan ikan) harus di tata ulang dan untuk kemasan perlu adanya design plastik kemasan yang lebih menarik. Dalam pelaksanaan program PKM, kami mendesign model kemasan Ikan Teri yang akan di cetak dan di sumbangkan ke para nelayan Desa Toniku. Design produk kemasan tersebut dapat dilihat pada Gambar 5 di bawah. 


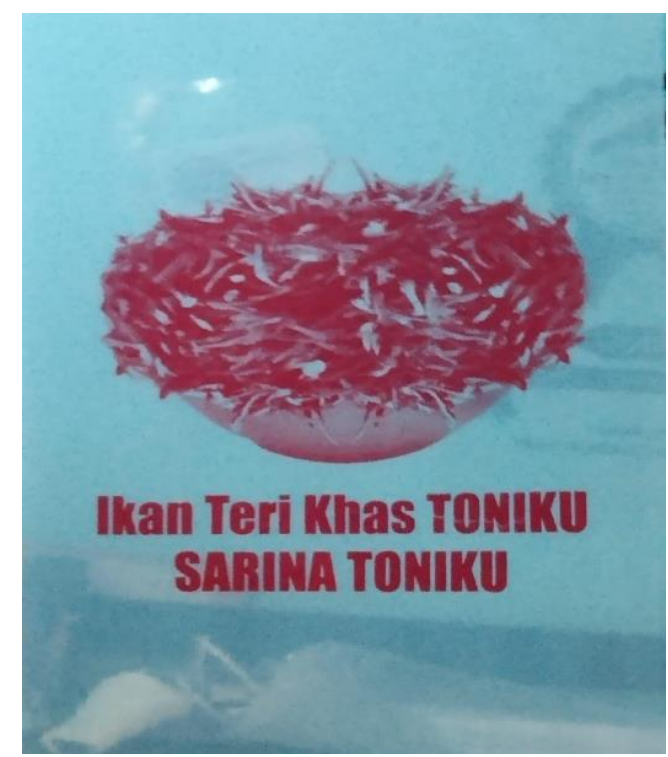

Gambar 5. Design Kemasan Produk Ikan Teri

\section{c. Pengemasan Ikan Teri di Desa Toniku}
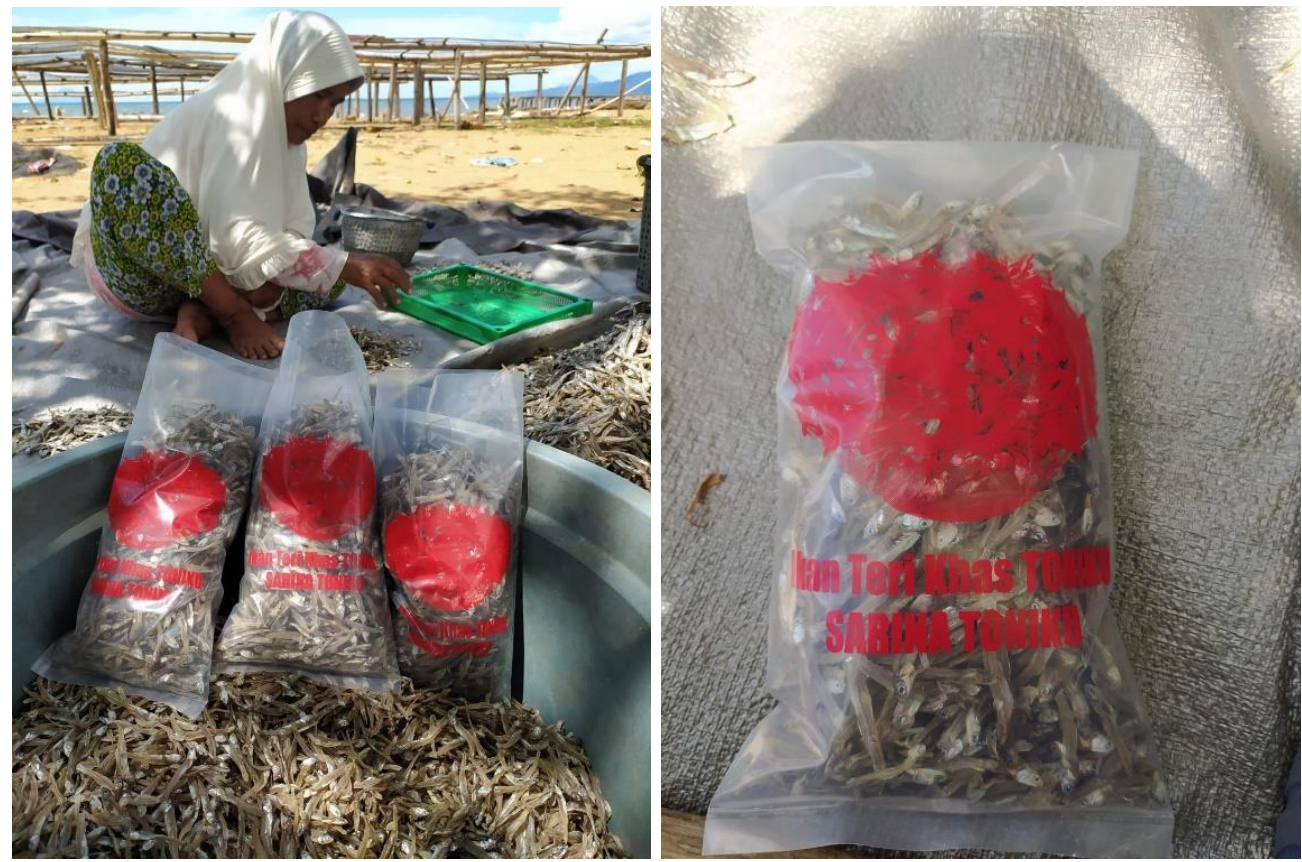

Gambar 6. Proses Pengemasan Ikan Teri

500 platisik kemasan produk telah dicetak dan diserahkan kepada para nelayan di Desa Toniku. Gambar 6 adalah proses pengemasan kemasan ikan teri yang dilakukan nelayan UD. SARINAH di Desa Toniku. Dengan adanya kemasan produk ini, maka nilai jual dari Ikan teri yang diproduksi tentu akan lebih tinggi serta terlihat lebih menarin dan higienis. 


\section{d. Solusi Pemasaran dan Pengemasan Ikan Teri di Desa Toniku}

Dari hasil survey dan analisa yang dilakukan, beberapa solusi terhadap permasalahan dari proses pemasaran dan pengemasan Ikan Teriyang dilakukan oleh Masyarakat Nelayan Desa Toniku antara lain sebagai berikut.

1. Proses Penyaringan Ikan

Metode penyaringan ikan secara tradisional yang pakai oleh masyarakat Desa Toniku tentu membutuhkan waktu yang cukup dalam dalam penyaringan permasalahan ini menjadi konser kami agar dapat menciptakan Teknologi Tepat Guna pembuatan alat penyaringan ikan sehingga dapat membantu masyarakat untuk mempercepat proses penyaringan ikan tersebut dan tentunya akan meningkatkan proses produksi mereka.

2. Pengemasan Ikan Teri

Untuk menjaga ikan teri yang di produksi bersih dan higienis serta terlihat menarik untuk di pasarkan maka design kemasan harus dilakukan. Tahapan pembuatan dan penyerahan kemasan telah dilakukan dan dibagikan kepada para nelayan di Desa Toniku.

3. Promosi dan Pemasaran

Untuk pemasaran dan promosi, kami telah mengambil beberapa foto dan video untuk selanjutkan akan dibuatkan Intagram serta youtube sebagai media untuk memprmosikan Ikan Teri Desa Toniku yang terkenal sangat berkualitas serta enak di konsumsi.

\section{Kesimpulan}

Adapun kesimpulan dalam pelaksanaan program PKM di Desa Toniku yaitu 90\% sudah tercapai. Dimana telah terlaksana pelatihan dan proses kemasan produk ikan yang siap dipasarkan,dan disarankan pada pengabdian selanjutnya di lakukan pengembangan model kemasan agar bisa masuk pasar nasional dengan menggunakan media sosial.

\section{Ucapan Terimakasih}

Terima kasih kepada Universitas Khairun dalam memberikan dukungan pembiayaan dalam kegiatan pengabdian masyarakat tahun 2021.

\section{Daftar Pustaka}

Erwanto, Z., \& Charles AT. (2001). Sustainable fishery systems. Canada: Blakwell Science Ltd. 370 p.

Craig, G. and Mayo, M. (eds) (1995) Community Empowerment. A Reader in Participation and Development. London: Zed Books. Pp. 1-11.

Dault, A. (2008). Pemuda Dan Kelautan. Jakarta: Pustaka Cidesindo.

Didiharyono, D., Tenrigau, A. M., \& Marsal, M. (2018). Pemanfaatan Sampah Plastik Untuk Dijadikan Bantal Yang Berkualitas Dan Bernilai Ekonomis 
Di Desa Tolada Kecematan Malangke Kabupaten Luwu Utara. To Maega: Jurnal Pengabdian Masyarakat, 1(1), 8-13.

Hikmat, A. (2006), Strategi Pemberdayaan Masyarakat. Bandung: Humaniora Utama Press. 240 hlm.

Ife, J. (1995). Community Development: Creating Community Alternatives-Vision, Analysis and Practice. Australia: Longman.

Mc-Ardle, J. (1989), “Community Development Tools of Trade”. Community Quar-terly Journal 16: 47-54 p.

MoleongLexy, J. (2007). Metode Penelitian Kualitatif. Bandung: Remaja Rosdakarya

Mukhlis, M., Kasmawati, K., \& Raznilawati Z., (2021), Bentuk Kepedulian Antar Sesama Lewat Berkah Ramadhan di Tengah Wabah Covid-19: To Maega Jurnal Pengabdian Masyarakat, vol 4, no 1, hal 55-62

Mulyadi, S. (2007). Ekonomi Kelautan. Jakarta: PT Raja Grafindo Persada.

Raznilawati, Z., (2017). Analasis Strategi Pemasaran Dalam Meningkatkan Volume Penjualan Pada Cafe Enzyme. Jurnal humano, Vol 8, No 1 (2017)

Satria, A. (2001). Dinamika Modernisasi Perikanan: Formasi Sosial dan Mobilitas Nelayan. Bandung: Humaniora Utama Press.

Siswanto, B. (2008). Kemiskinan dan Perlawanan Kaum nelayan. Malang: Laksbang Mediatama.

Suharto, E. (2005). Membangun Masyarakat Memberdayakan Rakyat. Kajian Strategi Pembangunan Kesejahteraan 